\title{
Ecological Impacts of Insecticides
}

\author{
Francisco Sánchez-Bayo \\ Centre for Ecotoxicology, University of Technology Sydney, \\ Australia
}

\section{Introduction}

Substances capable of killing insects and other pests were discovered by the Persians some 2500 years ago, but it was the Green Revolution since the 1950s that fostered the development of new synthetic pesticides to cope with the demands of the explosive human population. We have now reached 7 billion people and managed to reduce starvation in many underdeveloped countries. In fact, the world's agricultural productivity has increased 2.6-fold but the arable area has increased only by $10 \%$, mostly at the expense of our forests (FAO 2004).

Synthetic insecticides applied to a full range of crops soon started to have side effects in the surrounding natural ecosystems. The direct effects of insecticides on arthropod communities, and the birdlife that depends on them, was brought into question by Rachel Carson as early as 1962. It is not coincidence that the birth of the environmental movement and ecotoxicology was thus linked from its very beginnings to the widespread use of synthetic pesticides in agriculture and forestry. These fears became reality when the unrestrained over-use of these 'wonder chemicals' in Indonesia and the Philippines led to the collapse of their rice crops in the early 1970s. The destruction of predators within the complex food web of rice ecosystems released the pressure on pest species such as plant hoppers (Nilaparvata lugens), which devastated the crops. This love affair with chemicals ended when the Indonesian government banned many insecticides and restricted the use of other pesticides (Daryanto 1998). From then onwards farmers were encouraged to foster natural enemies that can control or at least avoid the onset of pests in agricultural ecosystems. Pesticides were not to be used alone, but in combination with other biological and agronomic practices that protect the ecosystem. Thus, the Integrated Pest Management (IPM) strategies, first proposed by the Food and Agricultural Organisation (FAO) of the United Nations in October 1965, started to replace the conventional Green Revolution practices. However, to grow enough food for us all is a major challenge faced by modern agriculture. Because the relentless expansion of our cities often demands that old, fertile agricultural land be converted to urban dwellings, our planet is actually running out of suitable land to grow food for the future generations.

This chapter deals with the known ecological impacts of insecticides on terrestrial and aquatic ecosystems, without consideration of the economic benefits that they may have. We must accept that pest control and disease eradication are complex issues that will never be resolved without causing problems to the environment -and there are not simple solutions to complex problems. Our aim should be to minimise the environmental impacts to levels that are acceptable by the society and bearable by the ecosystems. 


\section{Use of insecticides and acaricides}

Worldwide use of insecticides is estimated at over one million tons annually (FAO 2010), comprising some $28 \%$ of the total amount of pesticides used. Most of the insecticides are still produced and used in North America, Europe and Japan, but countries such as China and India are expected to take the lead in the coming years. In fact, while insecticide usage has remained stable or even declined in developed countries due to regulatory restrictions in favour of new agricultural trends (e.g. GM crops, organic agriculture), developing countries are producing large quantities of old and highly toxic insecticides that have already run out of patent. For example, insecticides make up $7 \%$ of the total pesticides used in Europe, 19\% in the USA, but 38\% in Asian countries and $86 \%$ in Africa.

Currently, there are about 460 chemical compounds used for controlling insects, mites and other invertebrates worldwide. Most of them are used as insecticides $(60 \%)$ or pheromones to attract insects $(14 \%)$, while some $24 \%$ are used to control mites (acaricides), and only a few to eliminate nematodes (nematicides) and snails (molluscicides). Here, all these products are referred to as insecticides so long as they are used for: i) protection of crops and produce from pests; ii) prevention of diseases in livestock and human populations; and iii) control of nuisance insects in urban settings and industrial facilities.

Farmers are by far the main consumers of insecticides. Indeed, about one fifth of the world land is dedicated to agriculture, with $12 \%$ of the area being cultivated and the remaining area used for livestock. In some European countries and in the USA, that proportion could be as high as $25 \%$ of the land. Most of the insecticides are applied directly to the crops to protect them against insect pests, but a small proportion is used to protect the harvested produce (mostly grain) in storage facilities before their distribution and transport to the market. The overall economic costs of insecticides in developed countries, including the actual products plus the cost of monitoring to ensure food safety, are between 1-2\% (UK) and $4 \%$ (USA) of the farm revenues (Pimentel 2005). However, in crops such as cotton insecticides can represent up to $20 \%$ of the running costs of a farm. Human health costs and fatalities should also be added to these economic costs.

Insecticides are also essential tools to eradicate disease vectors in tropical and subtropical regions. Tse-tse fly (Glossina sp.) and small blackfly (Simulium damnosum) eradication programs, conducted since the 1950s with insecticides, have reduced the incidence and risk of nagana and sleeping sickness (trypanosomiasis), and river blindness disease (onchocerciasis) among African peoples. Mosquito control using insecticide impregnated nets is very effective in preventing the spread of malaria and West Nile virus in tropical and subtropical regions. As a result of using new chemicals and improved eradication techniques the impacts on non-target organisms have been ameliorated significantly in recent years. This is a case where the risks to human health take priority over environmental impacts, which are recoverable and in the long-term have proven to be small compared to game extermination or bush clearing. In a similar way, prevention of diseases in livestock is achieved by pour-on and dip techniques using insecticides.

\section{Toxicity of insecticides at the individual level}

Organisms are affected by the toxicity of insecticides firstly upon direct exposure to these chemicals. The route of exposure is essential in determining the effects at the individual level. For example, after spraying a field crop with an organophosphorus (OP) insecticide, 
birds that receive the spray directly on the feathers may get more exposure and die sooner than those that simply inhale its vapour, or those that eat contaminated grain or insects. This is because the total dose of OP insecticides acquired through the skin or feathers is higher than that inhaled or ingested, and 'it is the dose that makes the poison' (Paracelsus). Ingestion, on the other hand, may be a more important route of exposure in the case of organochlorine (OC) insecticides because these are persistent and accumulate in the body so the exposure route depends to a large extent on the chemistry of each compound.

\begin{tabular}{|c|c|c|c|c|c|}
\hline Category & Crustaceans & Bees & Worms & Fish & Mammals, birds* \\
\hline & $\mu \mathrm{g} / \mathrm{L}$ & $\mu \mathrm{g} /$ bee & $\mathrm{mg} / \mathrm{kg}$ soil & $\mathrm{mg} / \mathrm{L}$ & $\mathrm{mg} / \mathrm{kg} \mathrm{b.w.}$ \\
\hline Highly toxic & $<10$ & $<1$ & $<10$ & $<1$ & $<50$ \\
\hline Moderately toxic (XX) & $10-100$ & $1-10$ & $10-100$ & $1-10$ & $50-500$ \\
\hline Slightly toxic & $100-1000$ & $10-100$ & $100-1000$ & $10-100$ & $500-5000$ \\
\hline Non-toxic & $>1000$ & $>100$ & $>1000$ & $>100$ & $>5000$ \\
\hline
\end{tabular}

* Acute oral LD50

Table 1. Toxicity categories for different taxa based on LC50 or LD50 values.

The toxicity and specificity of insecticides is a consequence of their biochemical mode of action at the cellular or physiological level in the organisms. Table 1 shows the toxicity categories for several commonly assessed taxa of non-target organisms. While the toxicity is determined by the internal dose required to cause the death of an organism, the specificity depends on the physiological mechanisms targeted by the insecticide, which can either vary substantially among taxa (selective) or be the same for all animals (broad-spectrum). Although originally intended to control insect pests, broad-spectrum insecticides are hazardous poisons to all kinds of animals, even if their lethal doses are necessarily higher for larger animals than for small insects. The mode of action of insecticides is well known for most compounds (see Chapter XX), and can be summarised in the following five major groups:

\subsection{Neurotoxic insecticides}

Their target is one of the five neurotransmitter systems -particularly cholinergic- found in the neuronal system of arthropods, which are either activated (agonist action) or inhibited (antagonist action) by the insecticide. Break down of the neuronal activity causes brain death or affects the motor system through paralysis, convulsions, hyperactivity and spasms.

a. Acetylcholinesterase (AChE) inhibitors comprise the organophosphorus (e.g. chlorpyrifos, dimethoate and 60 others) and carbamate (e.g. aldicarb, methomyl, pirimicarb and 25 others) insecticides. Since AChE is the main enzyme of nicotine and muscarine receptors of neurons and muscular junctions in animals, these are broadspectrum and very toxic poisons, especially to mammals and birds.

b. $\gamma$-aminobutyric acid receptors (GABA-R) are located in the post-synaptic dendrites of the central nervous system in all animals, but in arthropods also in the neuromuscular junctions and ganglia. The avermectins (e.g. abamectin) are particularly toxic to arthropods (i.e. zooplankton, macro-crustaceans and spiders) but not so much to vertebrates (Table 2); the cyclodiene OC insecticides (e.g. endosulfan) are more toxic to terrestrial animals and fish, and fipronil somewhere in between.

c. Nicotine acetylcholinesterase receptors (nACh-R) are located in the post-synaptic dendrites of all neurons in the brain, spinal cord, ganglia, and muscular junctions. 
Nicotine, neonicotinoids (e.g. imidacloprid, thiacloprid) and spinosad activate it, causing hyperactivity and death. The dithiols (e.g. cartap) block it, causing paralysis and eventually death. Since the $\mathrm{nACh}-\mathrm{R}$ is different in vertebrates, these insecticides are quite specific to arthropods, but dithiols are very toxic to birds as well.

d. Sodium channels are located in all neuronal membranes. In arthropods, fish and other aquatic animals these channels are kept open by DDT and analogue organochlorines, pyrethrins and synthetic pyrethroids (e.g. deltamethrin and 45 others), thus causing loss of nervous impulse (knockdown) and eventually death, whereas indoxacarb blocks sodium channels. Pyrethroids are the most toxic insecticides to fish and crustaceans (Table 2).

e. Octopamine receptor: amitraz inhibits this receptor involved in energy demanding activities in invertebrates (e.g. jumping, flying, light emission, etc), which is modulated by the dopaminergic system. In vertebrates this receptor is associated with noradrenalinergic systems, so with the exception of fish amitraz is not very toxic to vertebrates.

\subsection{Respiration inhibitors}

All of them are broad-spectrum insecticides that disrupt the mitochondrial oxidative phosphorylation system common to most animals. Some uncouple the complex I (e.g. rotenone), whereas dicofol targets complex II and others complex III, but for most (e.g. chlorfenapyr, diafenthiuron, DNOC, etc.) the exact target is unknown. In any case, they are very toxic to fish and worms, but not so toxic to vertebrates. ATPase inhibitors such as the organotins and propargite, which are used as acaricides, are quite toxic to fish and crustaceans. Fumigants are particularly toxic, especially to worms and birds, and so is chlorfenapyr (Table 2).

\subsection{Growth inhibitors and regulators (IGR)}

These are very selective insecticides that break the life-cycle of arthropod development and metamorphosis, so they are quite harmless to vertebrates and worms (Table 2).

a. Chitin biosynthesis inhibitors: benzoylureas (e.g. diflubenzuron), cyromazine and buprofezin disrupt growth in all arthropods, since they all have an exoskeleton made of chitin. Crustaceans, however, can be seriously affected by the residues in waters.

b. Mite growth disruptors (e.g. clofentezine) are selective to this taxon, and practically non-toxic for any other taxa except for crustaceans.

c. Ecdysone agonists: the steroidal hormone ecdysone, which prompts moulting in arthropods, is mimicked by azadirachtin and diacylhydrazines (e.g. tebufenocide). These compounds cause premature moulting in the larval stages of some insect taxa such as Lepidoptera -but not bees-, thus preventing them from reaching the adult stage in due time. Very selective and non-hazardous to other taxa.

d. Juvenile hormone analogues $(\mathrm{JH})$ : methoprene, hydroprene, kinoprene, pyriproxyfen and fenoxycarb are agonists that keep all insects (including bees) in their larvae stage, thus preventing the pupa to moult into adult. Selective, but can affect zooplankton too.

\subsection{Stomach poisons}

Cryolite, sulcofuron sodium and the toxins produced by Bacillus thuringiensis (Bt) destroy the midgut tissues in caterpillars, being therefore very specific to Lepidoptera insects but quite harmless to all other animals. 


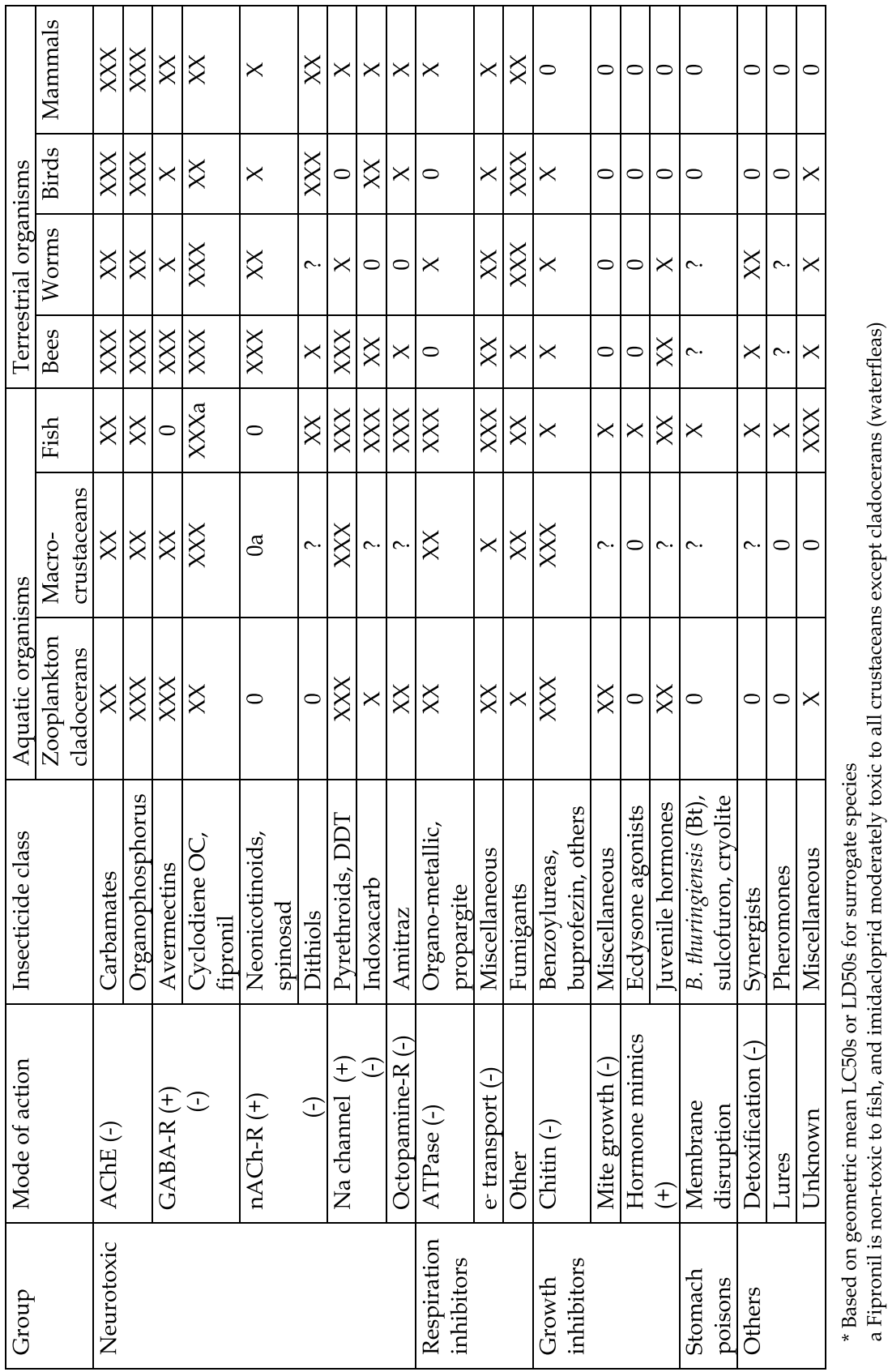

Table 2. Comparative toxicity* of insecticides to non-target organisms, according to their mode of action: agonists $(+)$, antagonists $(-)$. Symbols $(X, 0)$ indicate the toxicity categories as in Table 1: question mark denotes no data available. 


\subsection{Other modes of action}

Pymetrozine and azadirachtin have anti-feedant properties, but the mechanism involved in this action is not well understood. Synergists enhance the toxicity of other insecticides by inhibiting the cellular detoxification mechanisms (e.g. monoxygenases, cytochrome P450, etc), and are quite toxic to worms. Natural or artificial pheromones attract individuals of the same pest species (i.e. sex pheromones for females), being the most specific substances used in insect control and one of the safest for non-target organisms (Table 2).

When exposure to an insecticide is below its mortality levels, the individuals affected may undergo sublethal effects, i.e. negative side effects that are unrelated to the specific mode of action of that insecticide. Some examples are the reproduction impairment as a consequence of sperm deformity in earthworms caused by imidacloprid (Luo et al. 1999), the depressed immunological response of frogs to trematode infections (Rohr et al. 2008) and the disruption of endocrine regulatory systems in many organisms by a number of pesticides (Manning 2005). Sublethal effects are unpredictable so long as they are due to unknown physiological mechanisms. The best known sublethal mechanism is the thinning of eggshells in birds caused by accumulation of DDE and OC residues (Cooke 1973), which results in high frequency of eggs breaking and, therefore, in reproduction failure. Behavioural changes are also sublethal effects even if they may result from the neurotoxic activity of the insecticide. For example, bees exposed to low doses of permethrin are not actively involved with foraging, but spend their time rubbing legs, trembling, dancing and in self-cleaning activities (Cox and Wilson 1984). Frogs exposed to malathion have reduced predatory skills (Relyea 2004), and starlings exposed to OP insecticides neglect looking after their nestlings, thus causing early death of chicks and reproduction failure (Grue et al. 1982).

\section{Impacts on non-target populations}

Wild animals live in populations of few or many individuals in accordance with the distribution and behaviour of each species. Direct exposure to insecticides occurs in and around the sprayed crops, affecting usually a limited number of individuals of each population, not all. However, repeated exposures over time may have dire consequences for a given population when its reproductive capacity is impaired. Thus, population declines may result from direct toxicity, either through primary or secondary poisoning, or from sublethal effects manifested as reductions in life span, development rates, fertility, fecundity, sex ratio, and behaviour (e.g., feeding, foraging and reproduction).

\subsection{Terrestrial populations}

Impact of OP and carbamate insecticides on earthworms populations in agricultural fields and grasslands have been reported since the 1960s (see review in Brown 1978). Whilst all fumigants wipe out earthworms as they penetrate the deep layers of the soil, the majority of $\mathrm{OC}, \mathrm{OP}$ and carbamate insecticides do not cause significant reduction of earthworm populations at normal application rates (e.g. aldrin $2.5 \mathrm{~kg} / \mathrm{ha}$ ). However, endosulfan, parathion-methyl and carbaryl can cause $15-60 \%$ reductions, and chlordane, heptachlor, phorate and carbofuran are so toxic to worms that they eliminate them completely, although their numbers recover within a year if they are re-colonised from the surrounding area. Recovery times are usually 60 to 80 days, but following carbofuran treatments, can take 90105 days, and following application of the OC insecticide butachlor can be longer than a season. Replacement of those broad-spectrum insecticides with pyrethroids such as $\lambda$ - 
cyhalothrin has practically no impact on tropical earthworm populations because the latter class of insecticides is less toxic to earthworms (Table 2). Neonicotinoids are also safer to these organisms, but sublethal effects on earthworm burrowing activity have been observed after application of imidacloprid at $0.5-1.0 \mathrm{mg} / \mathrm{kg}$ in soil (Capowiez et al. 2006), as well as significant weight losses and 44-97\% less cast production within the typical range 0.33-0.6 $\mathrm{mg} / \mathrm{kg}$ of this insecticide in soil (Dittbrenner et al. 2010). Weight loss and cocoon production among earthworms are also seriously affected when concentrations of imidacloprid in the litter of treated forests exceed $3 \mathrm{mg} / \mathrm{kg}$ (Kreutzweiser et al. 2008). The latter effects obviously affect the viability of earthworm populations in the short-term.

The direct impact of insecticides on honey bees (Apis mellifera) was recognized as a problem since the calcium arsenate dust sprays killed entire hive colonies in the past (Brown 1978). Bees are insects, and so pyrethroid and OP insecticides are very toxic and hazardous to them (Table 2). An average of 50 poisoning incidents per year were confirmed in Great Britain between 1981-91, involving some 30 insecticides, of which triazophos, dimethoate, fenitrothion and lindane were the most common (Greig-Smith et al. 1994). Spray drift and volatilization are responsible for most of these incidents. Pyrethroids pose a high risk not just to honey bees but also to wild bumblebees (Bombus sp.), all of which play an important role in the pollination of many flowering plants and vegetable crops (Thompson 2001). Bees can also be killed by ingestion of contaminated nectar and pollen. The introduction in recent years of systemic insecticides such as imidacloprid has been blamed as the main cause of the declining bee colonies in France and other European countries, although not without controversy (Maxim and Sluijs 2007). Even if typical residues of imidacloprid in pollen (2.1 $\mu \mathrm{g} / \mathrm{kg}$ for a range of plants (Bonmatin et al. 2005)) from agricultural areas treated with this insecticide are below the oral LD50 for honeybees (18 ng/bee), chronic feeding on such pollen may lead to mortality of the bees. In addition to direct mortality, imidacloprid impairs the memory and activity of worker bees, which likely result in the failure to rear their larvae in the hive. Insecticides also affect the performance of the bee colonies, with impacts ranging from odour discrimination to the loss of foraging bees due to disruption of their homing behaviour.

Spraying crops and forests with OP and carbamate insecticides can cause temporary reductions in songbird populations by directly killing some individuals. However, casualties among birds are hard to observe and quantify due to their mobility and because dead birds are difficult to find in the surrounding treated areas. Evidence of impacts comes from sublethal effects observed in debilitated birds after the spraying: brain AChE bioassays confirm the depression caused by fenitrothion and aminocarb spray formulations but overall impacts of fenitrothion spraying on forest bird populations appear to be minimal. The effects of fenthion on the breeding success of red-winged blackbirds (Anglaius phoenicius) in USA were negligible (Powell 1984), and spraying of malathion, carbaryl and fipronil for locust control reduced some songbird populations in Wyoming but increased others; residual effects can be more important than the acute toxicity of the compounds when considering their overall impacts on bird populations. Impacts of repellent methiocarb sprays to protect cherry orchards against birds are transient and usually confined to sublethal effects (Hardy et al. 1993). Insecticide sprays to control vector diseases can also cause declines in some populations of birds, but most effects are sublethal: i.e. when malathion was sprayed in Haiti to control malaria.

Lack of apparent direct effects on bird populations can be masked, however, by immigration of individuals from nearby areas, a compensatory effect that is difficult to gauge for most 
species in the field. Small field enclosures (mesocosms) can be used to avoid this problem when experimenting with populations of small mammals, but not with birds. Thus, the impacts of endrin $(0.56 \mathrm{~kg} / \mathrm{ha})$ on populations of meadow voles (Microtus pennsylvanicus) and deer mice (Peromyscus maniculatus) were studied: while both species were reduced in numbers immediately after application of the insecticide, the voles recovered and achieved higher densities in subsequent years, whereas the mice never recovered fully (Morris 1970). Similar impacts have been observed with AChE inhibitors. For example, carbaryl sprayed on oats $(2.3 \mathrm{~kg} / \mathrm{ha})$ had different impacts on populations of small herbivorous mammals: while house mice (Mus musculus) increased in the treated fields, the population of meadow voles decreased due to a 5-6 week delay in pregnancies among their females (Barrett 1988). Sprays of azinphos-methyl $(2.44 \mathrm{~kg} / \mathrm{ha})$ on pasture mesocosms reduced populations of gray-tailed voles (Microtus canicaudus) when the applied pasture was dry, but not when it was wet (Wang et al. 2001), perhaps because under wet conditions this OP insecticide dissipates faster, so exposure to small herbivorous mammals is minimised. Another factor that reduced the exposure of voles to this insecticide was the density and height of vegetation, with populations decreasing in shorter alfalfa pastures but not in tall prairie grasses. It should be pointed that not all OP insecticides have impacts on vole populations (i.e. acephate), even if exposure of small mammals occurs and can be demonstrated using brain or plasma bioassays.

\subsubsection{Primary poisoning}

Primary poisoning by consuming insecticide granules is one of the most common causes of bird mortality, since birds mistake the granules as grit for their gizzards (Mineau 2003). Phorate, terbufos, fonofos, aldicarb and carbofuran are usually applied to crops in granular form to eliminate soil larvae. Given their extreme toxicity to birds and mammals (Table 2) they are very hazardous to wildlife around corn fields and other crops. Despite efforts to reduce their risk by modifying the colour of granules, incidents on wildlife populations are probably more common than we think because most of the fatalities pass unnoticed. For example, entire populations of waterfowl were decimated when ducks and geese ate fonofos granules that were still buried in potato crops a few months after they were applied. These birds use the fallow fields as wintering grounds, and sift the buried granules in their search for food (Elliott et al. 2008). Similar incidents have occurred with other granular OP and carbamate insecticides on many occasions. Songbirds and small mammals are equally killed by granular insecticides, and granivorous birds in particular are affected by insecticidetreated seeds. In the past, seed-dressing formulations of aldrin, dieldrin, heptachlor and lindane were common and caused a large number of deaths among geese. Their replacement with $\mathrm{OP}$ and carbamate insecticides still produces a substantial toll on birds in Europe and other countries. For example, 15 endangered sarus cranes (Grus antigon) and 3 common cranes were found dead near a National Park in India in November 2000. Analysis of their stomachs revealed residues of monocrotophos at levels $0.2-0.74 \mathrm{mg} / \mathrm{kg}$, while wheat seeds from the fields nearby had residues of $0.8-1.8 \mathrm{mg} / \mathrm{kg}$ of the same insecticide; the cranes had been eating contaminated wheat seeds and died because of the high toxicity of this OP insecticide to birds (Pain et al. 2004). Poisoning of songbirds, waders, seabirds and raptors by chlordane, lindane and DDT compounds was all too common in the past and is still occurring in North America, Japan, Russia and northern Asia, even though some OC compounds have been banned or restricted for use in agriculture (e.g. dieldrin, DDT). This is due to bioaccumulation of the persistent $\mathrm{OC}$ insecticides in organisms, which occurs 
whenever the rate of intake is higher than the metabolic rate (degradation) of the compound in the body.

\subsubsection{Secondary poisoning}

Secondary poisoning of predators consuming contaminated prey often results in mortality, since the toxic dose ingested by the predator is usually higher than the residue concentrations found in soil or water: as a predator consumes contaminated prey, it accumulates more and more residues in its own body. This can continue up through the food chain through a process called biomagnification, thereby causing sickness and mortality among higher-level predators. This phenomenon is more prevalent among persistent insecticides. For example, more than 96\% of lacewings (Micromus tasmaniae) were killed after feeding on lettuce aphid (Nasonovia ribisnigri) contaminated with imidacloprid applied at recommended rates $(20-30 \mathrm{ml} / 1000$ lettuce plants), whereas pirimicarb and pymetrazine only caused a $30-40 \%$ or less than $20 \%$ mortality, respectively, when applied also at their recommended rates (Walker et al. 2007). Most cases of secondary poisoning are reported for predatory vertebrates. Thus, OP and carbamate insecticides have been implicated in the mortality of many raptors in Europe and North America over the years (see review in Mineau et al. 1999). In countries with less or no regulation the impacts of these highly toxic insecticides can be devastating: for example, about 6000 Swainson's hawks (Buteo swainsoni) were found dead in the Argentinian pampas in 199596 after eating grasshoppers that were contaminated with monocrotophos, which was used to control a locust outbreak (Goldstein et al. 1999), and hundreds of raptors (birds of prey and owls) suffered the same fate in Israel in 1975-76 when a plague of levant voles (Microtus guentheri) in alfalfa fields was suppressed with a monocrotophos spray (Mendelssohn and Paz 1977). Although these are isolated incidents, it is obvious that this particular OP insecticide is too hazardous to be used in such circumstances. Populations of insectivorous vertebrates are particularly affected by secondary poisoning. For example, it is believed that populations of free-tailed bats (Tadarida brasiliensis) in New Mexico suffered a severe decline since 1936 due to ingestion of insects with high levels of insecticides (Clark 2001). Deer mouse (Peromyscus maniculatus) densities in grassland enclosures receiving $3.61 \mathrm{~kg} / \mathrm{ha}$ of azinphos-methyl decreased $47 \%$ within 5 days after spraying because the mice fed on contaminated arthropods (Schauber et al. 1997). Since most reptiles and frogs are insectivorous, their exposure to pesticides is mainly through preying on contaminated insects and, in the case of snakes, other vertebrates as well. Early reports showed that sprays of $5 \mathrm{~kg} / \mathrm{ha}$ of DDT to control cattle ticks in Texas resulted in the deaths of snakes, spiny lizards and probably many other reptiles in the prairie (George and Stickel 1949). However, not much information is available on the impacts that OP insecticides have on reptile populations, even if data on residues of OC insecticides and AChE inhibition can provide some indication about their levels of exposure.

\subsubsection{Sublethal effects}

In addition to direct mortality by poisoning with insecticides, wild populations can be reduced through sublethal effects on the reproduction of some species. For example, experimental prairie grasslands treated with diazinon reduced the reproductive capacity of the omnivorous cotton rat (Sigmodon hispidus) by $33-100 \%$ as it fed on contaminated arthropods, but did not affect herbivorous voles (Sheffield and Lochmiller 2001). Sublethal effects are normally detected after many years of observations that show declining trends in 
the population of some species. The best known cases refer to fish-eating birds and raptors contaminated with DDE (a metabolite of DDT) and other OC insecticides. Sublethal effects of DDE were first identified by Ratcliffe (1967) in populations of peregrine falcon (Falco peregrinus) in Britain, which experienced an unusually high rate of hatching failure (28\%) due to breakage of their eggshells. Although OC insecticides had already been linked to declining populations of golden eagles (Aquila chrysaetos) in Scotland, the mechanism by which DDT and cyclodiene insecticides were affecting birds of prey was not solved until it was found that DDE metabolite interfered with calcium deposition during the eggshell formation, leading to thinner shells that were prone to breakage. The high breeding failure among Spanish imperial eagles (Aquila adalberti) between 1972 and 2003 was mainly due to DDT residue accumulation in their eggs (Hernández et al. 2008). This insecticide is also a contributing factor for the declining populations of booted-eagles (Hieraetus pennatus), goshawk (Accipiter gentilis), and possibly other birds of prey in Spain, despite the many years elapsed since DDT was banned from use in agriculture. Cyclodiene insecticides were also involved in reproductive failures. For example, accumulation of dieldrin in British sparrowhawks (Accipiter nisus) during the 1960-70s resulted in population declines of up to $60 \%$ per year due to a combination of direct mortality and hatching failure; after the cyclodiene insecticides were banned, the sparrowhawk populations recovered (Sibly et al. 2000). Among fish-eating birds, the hatching failure (32\% eggs) of double-crested cormorants (Phalacrocorax auritus) in Lake Michigan during the 1994-95 seasons was mainly due to DDE residues, not to dieldrin or polychlorinated biphenyls (PCB), even if DDT was banned for use in the area some 25 years earlier (Custer et al. 1999). Similar conclusions have been drawn from studies on populations of brown pelicans (Pelecanus occidentalis) in South Carolina, Louisiana and Florida during the 1960-70s, of common terns (Sterna hirundo) in the Canadian Great Lakes during the 1980s, and great blue herons (Ardea herodias) in the upper Mississippi river during the 1990s. However, the effect of DDE residues in the reproductive success of black-crowned nightheron (Nycticorax nycticorax) in New England and North Carolina colonies appeared to be minimal (Custer et al. 1983). Many other predatory bird populations have been affected by DDT, but fortunately most of them are now recovering after this and other OC insecticides were banned in most developed countries.

Endocrine disruption by insecticides was found when populations of American alligator (Alligator mississippiensis) from Lakes Apopka, Griffin, and Okeechobee in central and south Florida were investigated in 1984 after a spill of dicofol and DDT. Although OC residues in their eggs appeared to bear not relation to the hatching success of the colonies, further research linked the declining population trends in lake Apopka to developmental abnormalities in the gonads, which were due to sex hormonal imbalances that resulted in fewer males being born (Guillette et al. 1995), and males having poorly organized testes and abnormally small phalli. The combination of sublethal levels of DDT, its metabolite DDE and PCB residues in bald eagles (Haliaetus leucocephalus) from the Great Lakes region of North America has resulted in the so-called Great Lakes embryo mortality, edema and deformities syndrome (GLEMEDS), of which the most obvious consequence is a reproduction impairment that hampers the viability of populations of this endangered species. Various endocrine disruptive effects have been found among a wide range of species and taxa exposed to some insecticides (see review in Manning 2005). For example, hyperthyroidism in birds with sublethal levels of p,p'-DDT was shown as early as 1969, and 16 day-old chicks of tree swallow (Tachycineta bicolor) showed abnormal thyroid development after being exposed to carbamate, OP and pyrethroid insecticides sprayed on 
apple orchards (Bishop et al. 1998). However, since these effects are subtle and difficult to assess, their impacts on wildlife populations are largely unknown.

\subsection{Aquatic populations}

Populations of aquatic organisms are also affected by exposure to insecticides that find their way to the rivers, ponds and other water bodies either through spray drift or through runoff from agricultural fields. Anecdotal accounts of fish kills and declining fish populations due to pesticides are common, but rigorous studies on the impact that individual or mixture insecticides have on particular species are rarer. Lockhart et al. (1985) showed that malathion sprayed at $210 \mathrm{~g} / \mathrm{ha}$ for mosquito control in Winnipeg caused small temporary decreases in both catch of young walleye (Stizostedion vitreum) per unit effort and weight gains after the first spray. A reduction in AChE activity to about $25 \%$ of pre-exposure levels was estimated as the approximate threshold for population effects on this species of fish. Similar findings were reported in Haiti after spraying with malathion to control malaria vectors (McLean et al. 1975). Based on profenofos residues and AChE activity in wild fish, populations of European carp (Cyprinus carpio), bony bream (Nematalosa erebi), and mosquitofish (Gambusia holbrooki) are probably reduced during the peak contamination events in rivers from cotton-growing areas in Australia (Kumar and Chapman 2001). However, impacts of OP insecticides on fish populations under field conditions are likely to be minimised by the fast hydrolysis of these compounds. In the case of pyrethroids, the presence of organic matter and suspended solids in streams and rivers reduces considerably the exposure of fish to the insecticides. For example, pulses of cypermethrin applied to transgenic soybeans in the Rolling Pampas of Argentina did not result in direct mortality of the native fish Cnesterodon decemmaculatus, despite residue concentrations after spraying reaching comparable levels to the $96-\mathrm{h} \mathrm{LC} 50$ for this species $(0.43 \mu \mathrm{g} / \mathrm{L})$. The reason was the 12 -fold reduction in exposure due to sequestering of residues by water particles rich in organic content (Carriquiriborde et al. 2007). Avoidance behaviour may also explain the lack of exposure of some species in natural situations. For example, populations of the freshwater amphipod Gammarus pulex migrated downstream when exposed to pulses of fenvalerate and parathion-methyl in agricultural streams, thus avoiding direct mortality (Schulz and Liess 1999). Similar findings were reported for populations of macrocrustaceans (Hyalella curvispina and Macrobrachium borelli) in two streams of the Argentine pampa exposed to chlorpyrifos, endosulfan and $\alpha$-cypermethrin: mortality was high during the peak pulses, but declined further downstream due to migration (Jergentz et al. 2004). Populations of ostracods in rice fields are reduced significantly when treated with carbufuran, endosulfan or imidacloprid applied at their recommended field rates. Because zooplankton and epibenthic crustaceans are very sensitive to pyrethroid, carbamate, OC and OP insecticides (Table 2), they can be used as sentinel species to evaluate impacts of these chemicals. Pulse exposures of insecticides eliminate or reduce most populations of zooplankton species, but their recovery usually takes place within 15 days to 1-2 months (van den Brink et al. 1996). Recoveries depend on the residue levels in water, intraspecific competition for food and external predation pressures, as well as the presence of refuges that protect from exposure.

As with terrestrial populations, aquatic organisms are more likely to be affected in their growth and reproductive ability. For example, while the LC50 of fipronil to the estuarine copepod Amphiascus tenuiremis is $6.8 \mu \mathrm{g} / \mathrm{L}$, concentrations of this insecticide in water at 0.22 
$\mu \mathrm{g} / \mathrm{L}$ reduced female egg extrusion by $71 \%$, whereas $0.42 \mu \mathrm{g} / \mathrm{L}$ almost eliminated reproduction (94\% failure) (Chandler et al. 2004). Extinction of Daphnia pulex populations occurred at concentrations $80 \mu \mathrm{g} / \mathrm{L}$ of fipronil, which is just above the NOEL threshold but higher than predicted environmental concentrations of this insecticide when applied for fruit fly control (Stark and Vargas 2005). Sublethal concentrations of fipronil and several pyrethroids up to 4.3 times lower than the LC50 for some compounds result also in growth inhibition of Chironomus sp. larvae. Given the life cycle of these organisms, lack of emergence into adult midges leads to ecological impacts similar to mortality, since their populations became reproductively non viable. Indeed, the zooplankton species Daphnia pulex went to extinction after exposure to a Neemix concentration of $0.45 \mathrm{mg} / \mathrm{L}$ (azadirachtin) even though the LC50 is $0.68 \mathrm{mg} / \mathrm{L}$. This is because the number of offspring per surviving female declined to the point that no reproduction occurred at the sublethal concentrations (Stark 2001). Similar outcomes were observed with exposure of the copepod Eurytemora affinis to dieldrin, which resulted in no population growth at $10 \mu \mathrm{g} / \mathrm{L}$ whereas the LC50 is $23 \mu \mathrm{g} / \mathrm{L}$, as well as populations of Daphnia magna and D. pulex exposed to spinosad, and Moina macrocopa exposed to the insect growth regulator methoprene. Pulses of esfenvalerate at concentrations in the range $0.1-0.6 \mu \mathrm{g} / \mathrm{L}$ can negatively affect Gammarus pulex survival, pairing behaviour, and reproduction even 2 weeks after the initial exposure. These amphipods are very sensitive to esfenvalerate, and exposure to $0.05 \mu \mathrm{g} / \mathrm{L}$ for $1 \mathrm{~h}$ led to immediate disruption of reproducing pairs, release of eggs or offspring from the brood pouch and, following transfer to clean water, subsequent delays in pair formation and reproduction (Cold and Forbes 2004).

Apart from direct impacts on survival and reproduction, cypermethrin appears to affect the swimming ability of Daphnia magna exposed to typical sublethal concentrations ( 0.05 and 0.6 $\mu \mathrm{g} / \mathrm{L}$ ) occurring in freshwater systems after its application. Inevitably, impaired swimming ability results in significant feeding reduction of the waterfleas. The European seabass (Dicentrarchus labrax) exposed to fenitrothion experienced similar effects. Other sublethal effects observed in fish include abnormal structure of the testis of bluegill (Lepomis macrochirus) exposed to $60 \mu \mathrm{g} / \mathrm{L}$ of diazinon (Dutta and Meijer 2003) and vertebral malformation in medaka fry exposed to $5-10 \mathrm{mg} / \mathrm{L}$ of carbaryl (Kashiwada et al. 2008). The high toxicity of endosulfan to adult frogs and tadpoles of various species is not mitigated by increases in water temperature in the subtropical and tropical regions where this insecticide is still applied; on the contrary, it seems that sublethal exposures $(0.8 \mu \mathrm{g} / \mathrm{L})$ of Litoria citropa tadpoles to this insecticide result in higher subsequent vulnerability to predation by dragonfly larvae (Broomhall 2002).

\section{Impacts on terrestrial communities and ecosystems}

Community impacts result from both direct effects on populations and indirect effects caused by the removal of prey species and/or competition from other species in the ecosystem. They have mainly been studied in mesocosms and microcosms, as these smallscale ecosystems, comprised of assemblages of a few taxa, allow monitoring under controlled experimental conditions. Impacts of insecticides on these communities affect the whole ecosystem, often resulting in functional changes that depend on the specific structure of all integrating communities. Thus, concerns over the insidious effects of pesticides operating through the disruption of the food chain structure are justified. 


\subsection{Soil communities}

Impacts of insecticides on micro-organisms are mixed, because negative effects on one group may favour another group. For example, chlorpyrifos altered temporarily the structure of saprophytic communities of treated groundnut fields in India: the bacterial communities were inhibited for two months while the fungi communities increased concomitantly. The impact of quinalphos was similar, except that this OP insecticide also reduced the fungi in the soil. Soil protozoa can also be disturbed by insecticide applications, as their populations do not usually recover within 60 days (Foissner 1997). However, carbofuran can foster the nitrogen-fixing bacteria associated with the rice rhizosphere, with populations of Azospirillum sp., Azotobacter sp. and anaerobic nitrogen-fixing bacteria increasing progressively with a successive number of applications.

Spray drift of chlorpyrifos and azinphos-methyl applied to orchards in South Africa reduced significantly the earthworm communities in neighbouring areas, even if soil concentrations of these OPs were very low: $0.2-2.7 \mathrm{mg} / \mathrm{kg}$ and $1.6-9.8 \mathrm{mg} / \mathrm{kg}$, respectively (Reinecke and Reinecke 2007). Phorate can also foster enchytraeid worms indirectly by eliminating their predators. In flooded soils such as rice fields, insecticides reduced populations of aquatic oligochaetes in the soil, although no significant long-term effects are observed. Some longterm studies have shown that insecticide-treated fields had no ecologically significant impacts in earthworm communities when compared to untreated fields, the differences being largely consistent with the expected effects of climate, soil types, crop types and cultivation practices.

Since the early days of pesticide usage it was realised that OC insecticides had negative or mixed effects on soil microfauna. The suppression of springtails (Collembola), saprophagous mites, symphilids and paurapods (Myriapoda) by insecticides is of concern. Paurapods seem to be most susceptible to OCs, and some communities can be completely eliminated by OP insecticides. Symphylids feed on plant rootlets, and because they live in the deep soil layers are less affected by treatments of OC and pyrethroid insecticides; however, systemic OP insecticides and fumigants can cause serious reductions in all taxa (see review in Edwards and Thompson 1973). Negative impacts of OP and carbamate insecticides on these tiny animals of the soil have also been observed, although the altered structure of their communities in soil microcosms treated with dimethoate did not disrupt the nutrient dynamics. Millipedes are more tolerant to broad-spectrum insecticides, but their populations declined over the years in cabbage plots treated with DDT, because residues of this persistent OC accumulated in their bodies, thus reducing their reproductive capacities (Brown 1978).

Mites are the most numerous arthropods in soil, with many of them being predators or saprophytic while some Tetranychus species are crop pests. Predatory mites are more affected when crops are treated with OC, OP and carbamate insecticides (Edwards and Thompson 1973). Although mite populations recover within six weeks to a few months, the elimination of the most susceptible Gamasina predacious mites by a single application of aldicarb at $25 \mathrm{~kg} / \mathrm{ha}$ resulted in a different community structure developing in the subsequent four years (Koehler 1992). Even natural insecticides like neem extracts (azadirachtin) are more detrimental to oribatid mites than other mites and spiders. A commonly observed outcome of insecticide application is the release of prey species due to reduced predatory pressure. For example, springtails usually increase in numbers when fields are treated with recommended doses of OC and pyrethroid insecticides, since the mites that prey on them are more susceptible than their prey (Badji et al. 2007). However, chlorpyrifos decimates springtail populations and changes the structure of their 
communities in soil, which take more than a year to recover. Ground spiders were also significantly reduced in British upland grasslands treated with chlorpyrifos (1.5 L/ha) even if their diversity remained similar to the non-treated plots. Consequently, one collembolan species, Ceratophysella denticulate, increased and dominated $(>95 \%)$ the community due to lack of predatory mites and competition with other springtails (Fountain et al. 2007).

Non-target communities of ground arthropods (e.g. carabid and staphylinid beetles, ants, earwigs, centipedes and spiders) are usually decimated when broad-spectrum insecticides are aerially sprayed to agricultural fields, orchards or to control locust outbreaks. For example, more than $75 \%$ of springtails, ants and Tenebrionidae beetles were eliminated after spraying with fenitrothion in Madagascar, but most populations recovered within a year. A combination of fenitrothion and esfenvalerate did not affect as many arthropods, although spiders were more affected and springtails did not recover in one year (Peveling et al. 1999). Ants appear to be the most sensitive non-target taxon to sprays of AChE inhibitors (carbaryl, malathion) and the IGR diflubenzuron. The IGR triflumuron, by contrast, controlled the locust but had little impacts on most arthropod communities with the exception of some butterflies, Hymenoptera predators and parasitoids. The impact of modern insecticides on the latter taxa can be a concern in IPM programs aimed at preserving the biocontrol potential of parasitoids. Thus, spinosad has little effect on most predatory insects, but $78 \%$ of laboratory studies and $86 \%$ of field studies show its harmful impact on hymenopteran parasitoids through sublethal effects that include loss of reproductive capacity, reduced longevity, etc, which lead to the decline of their populations (Williams et al. 2003). Grounddwelling carabid and staphylinid beetles make up about $75 \%$ of the predaceous and/or parasitic insects that control many crop and horticultural pests. Most OC insecticides reduce their populations and allow very slow recovery afterwards, whereas endosulfan at $1 \mathrm{~kg} / \mathrm{ha}$ appears not to cause major impacts on these arthropods (Wiktelius et al. 1999). The impact of AChE inhibitors on carabid populations ranges widely among species, with carbaryl at $2.26 \mathrm{~kg} / \mathrm{ha}$ in corn plantations having little impact (Whitford and Showers 1987). Pyrethroids and imidacloprid at recommended rates have also minimal impacts on these ground communities in spite of their high toxicity to insects (Sánchez-Bayo et al. 2007; Wiktelius et al. 1999).

Treatment of livestock with pour-on insecticides to control ectoparasites may have an unfortunate drawback: residues of the active compounds used (e.g. famphur, cypermethrin, spinosad, cyromazine, avermectins, fluazuron, etc.) are usually excreted and concentrated in the dung, thus killing fly maggots and dung beetles that recycle the cowpats. This causes structural changes of the saprophytic community through a reduction of species diversity and increase in dominance of less susceptible species. For example, emergence of the dung beetle Liatongus minutus and eight species of flies from cowpats in the first two weeks following ivermectin treatment at normal rates $(0.5 \mathrm{mg} / \mathrm{kg}$ body weight) was significantly reduced, while Ceratopogonidae and Psychodidae species prospered (Iwasa et al. 2005). These impacts can occur while lethal levels of residues persist in the dung - usually 1-3 weeks for most pyrethroids and avermectins in cowpats (Krüger and Scholtz 1997), but shorter times in sheep dung. However, IRG like fluazuron and methoprene appear to have no such effects at normal rates of treatment (Niño et al. 2009).

\subsection{Arthropod communities of vegetation}

As might be expected, the highest impacts occur in communities of arthropods of the crop and surrounding areas. Since the early years of the Green Revolution entomologists realized the limitations of using insecticides that killed over $95 \%$ of the insect pest as well as many 
non-target and beneficial insects. Indeed, elimination of natural predators usually results in the rebound of pest populations, and sometimes even in the creation of new pests. For example, carbofuran and chlorpyrifos applied to maize crops in Nicaragua reduced the foraging activity of predatory ants, thus resulting in the rebound of the noctuid Spodoptera frugiperda and the cicadellid Dalbulus maidis pest populations (Perfecto 1990).

Predatory arthropods keep the populations of insect pests in check. Ladybird beetles, dragonflies, earwigs, some ants and crab spiders predate on eggs of pest species: bollworm (Heliothis sp.) egg predation can be as high as 30-37\% per day in cotton crops not treated with insecticides. Among the insecticides applied to tea plantations in India, pyrethroids and ethion suppressed populations of predatory Syrphis sp. and the ladybird Coccinella septempunctata for over a week, endosulfan only affected the ladybirds, whereas neem and Bt formulations did not impact on the predators (Sharma and Kashyap 2002). Testing the susceptibility of natural predators to insecticides has become a necessity in many developing countries. It appears that pyrethroids are harder on predators than OP and OC insecticides, perhaps because insects in all larval stages are very susceptible to these kind of insecticides. Parasitic Hymenoptera also play an essential part in controlling numerous pest larvae. A recent review of 39 ecosystems found that agrochemical pollutants negatively affect these parasitoids in $46 \%$ of cases (Butler et al. 2009), with persistent and systemic insecticides (e.g. cartap and imidacloprid) having the greatest impacts. However, predatory arthropods are less susceptible than parasitoids and more variable in response to pesticides, with some predatory species being very tolerant to pesticides (e.g. the spider Lycosa pseudoannulata, the coccinellid Cryptolaemus montrouzieri, and the lacewing Chrysopa carnea). Early insecticide impacts on non-target arthropod communities were reported for orchards sprayed during three years with lead arsenate and nicotine. Ground-dwelling beetles, spiders and ants were reduced by $15 \%$, and the proportion of eggs and larvae of the main apple pest - the coddling moth (Laspeyresia pomonella), which is parasitized by Hymenoptera species - decreased by $64-97 \%$, allowing the moths to come back unopposed. DDT sprays helped eliminate the coddling moth, but it created new pests among leaf-rollers, woolly aphids, red-spiders and Tetranychus mites that surged as a consequence of the lack of predators and the suppression of parasitism. Citrus orchards sprayed with DDT to control cottony-cushion scales and mealybug pests also eliminated the predatory ladybird beetles and parasitoids - as a result, pest numbers not only did not decrease but rather surged exponentially. Because of the persistence of DDT, restoration of a normal predator-prey relationship after cessation of sprays could take up to five years (Pickett 1962). Replacement of such chemicals with other broad-spectrum insecticides did not improve the situation, as ground beetles, spiders, harvestmen, earwigs, and centipedes, which are predators of lepidopteran and homopteran pests of apple, were suppressed as well, whereas mites, slugs and snails were less affected (Epstein et al. 2000).

The annihilation of predatory and parasite arthropods in cotton, corn, rice and horticultural crops has created new community structures characterized by the absence of predator-prey relationships, one where pests species thrived for a while until the next insecticide spray decimates them, where resurgence became the norm and resistance to chemicals the final outcome (see review in Brown 1978). Pest management plans in cotton agroecosystems continued to rely on the routine and heavy use of pyrethroids, OPs, carbamates and new insecticides until the 1990s. Recently, the introduction of transgenic Bt-cotton in some countries appears to have had a positive effect on restoring the biodiversity of most predatory insects, spiders and birds in cotton fields, since insecticide applications are 
reduced 50\% or more (Wadhwa and Gill 2007). Similarly, the biodiversity of arthropods in Bt-corn crops is much higher than in fields treated with pyrethroids like $\lambda$-cyhalothrin, which can reduce the natural enemy community by $21-48 \%$ in a single application or by $33-$ $70 \%$ in five applications (Rose and Dively 2007). The only indirect effect of Bt crops appears to be a reduction in parasitoids, as the Bt toxins tend to eliminate the host Lepidoptera larvae. Apart from transgenic crops, IPM strategies aimed at increasing predatory populations in cotton crops include the use of supplementary food sprays together with virus applications, which can reduce insecticide use by $50 \%$ without sacrificing cotton yield and profitability. Another strategy relies on the application of IGRs such as buprofezin or pyriproxyfen, which reduce significantly the impact on predatory taxa compared to conventional treatments with broad-spectrum insecticides. Insecticide sprays on rice crops upset natural enemy control of pests such as plant hoppers (Nilaparvata lugens) and also create heavy selection pressure for strains of pests that can overcome previously resistant rice cultivars. Such circumstances create outbreaks of secondary pests and impair biological control of some key primary pests such as Pyralidae stem borers. Typical applications of BHC and parathion significantly decreased densities of predatory dragonflies, spiders and parasitoids, thus increasing the herbivore:predator ratio among arthropods. The insecticides imidacloprid and fipronil also change this ratio even if their main impact appears to be on midge larvae (Chironomidae). As with corn and cotton, transgenic Bt-rice can also help reduce the impact on predators, since the cry1Ab toxins do not affect Cyrtorhinus lividipennis, the main predator of planthoppers (Chen et al. 2007). The rich biodiversity of rice fields in tropical countries, with some 200 species of predatory arthropods, can be successfully used in IPM programs to control the 55 species of pests found in this crop.

Spiders and phytoseiid mites are important predators in all kinds of crops. Applications of OP, carbamate and pyrethroid insecticides in vineyards, orchards and other crops usually result in increases of pest Tetranychus mites because of reductions in the more susceptible phytoseiid predators. Chlorpyrifos and isofenphos applied to blue turf grass in Kentucky had the greatest impact (6 weeks) on predaceous mites, while effects of bendiocarb and trichlorfon were less severe and more temporary. By contrast, oribatid mites were apparently unaffected by the insecticides. The pyrethroid $\lambda$-cyhalothrin eliminated most pest and predatory mites alike in sprayed apple orchards in Canada (Li et al. 1992), whereas predatory phytoseiid mites survived well in vineyards treated with sulphur and copper but not with synthetic insecticides in South Australia (James and Whitney 1993). In experimental plots, spiders were three times less abundant in apple orchards treated with insecticides than in untreated ones, whereas spiders and ants populations were reduced in $53 \%$ of the corn crops treated with lindane $(0.5$ $\mathrm{ka} / \mathrm{ha}$ ) in Africa, an effect that lasted 2-3 weeks (Wiktelius et al. 1999). Lycosidae and linyphiid spider populations undergo a similar pattern - they are initially eliminated from cereal fields treated with OP insecticides, but their abundance may increase subsequently in response to rebound densities of unaffected prey like springtails.

In a few cases, however, the use of insecticides to control introduced pests can overcome the ecological damage that would follow if the pest were left unchecked. For instance, the exotic gypsy moth (Lymantria dispar) is invading the forested ecosystems in North America. The defoliation caused by outbreaks of this species has severe environmental impacts: death of oak trees, which results in less acorn production leading in turn to reduced populations of squirrels; outcompeting the native tiger moths (Arctiidae) for food; increasing bird nest predation as visibility increases due to lack of canopy; and replacement of oaks with maple trees, thus altering the foraging patterns of large mammals such as deer and bear. Spraying 
the affected forests with Bt insecticides, which has practically no impacts on non-target species, avoids the cascade of ecological impacts caused by the moth (Thompson 2011).

\subsection{Vertebrate communities}

Insecticides indirectly affect insectivorous vertebrates by reducing the insect prey base available to them. For example, populations of insectivorous birds such as white-headed black chats (Thamnolaea arnoti) can be reduced by $74-88 \%$ when their food supply disappears after spraying with DDT for tse-tse control in Africa (Douthwaite 1992).

The best documented evidence of indirect pesticide effects on bird populations is found in the United Kingdom, where declines of the grey partridge (Perdix perdix) had been noticed by game hunters and ornithologists for some time - it was rightly attributed to the combined indirect effect of herbicides and insecticides that resulted in breeding failure as a consequence of chick starvation and low survival (Potts 1986). In addition, other contributing factors such as worm parasites have added to the partridge demise. Since insecticides are routinely sprayed on cereal and other crops everywhere they have been indirectly affecting the food supply of many bird populations, some of which are declining in European countries and North America (Donald et al. 2001; Peakall and Carter 1997). Declining bird species (e.g. song thrush, spotted flycatcher, etc.) are not associated with particular foods, but with overall reductions in abundance and diversity of plants, seeds and insects as a result of intensive agriculture and loss of habitat. Although such declines are primarily driven by herbicide use and the switch from spring-sown to autumn-sown cereals, both of which have massively reduced the food supplies of granivorous birds (Newton 2004), insecticides account for a large part in those impacts, as most phytophagous birds supplement the diet of their offspring with insects. During the bird breeding season, grasshoppers, sawflies, spiders, leaf-beetles, weevils, butterflies/moths and their larvae, aphids, and crane-flies and their larvae are important foods for insectivorous, omnivorous and granivorous birds. The first four insect taxa are associated with the diet of most declining bird species and are also very susceptible to most insecticides even if birds may be tolerant. Failure to rear their young subsequently results in lower reproductive rates that can bring demise to some species. Recovery of plant and insect densities can be achieved in a few years once the intensive management practices are abandoned, offering hope for the recovery of birds as well.

It is reasonable to assume a similar fate in small insectivorous mammal and reptile populations, but at present evidence from field studies on these animal taxa is scarce (reviewed by Story and Cox 2001). For example, fenitrothion sprayed to control an outbreak of jack pine budworm (Choristoneura pinus) in pine plantations in Canada reduced populations of shrews indirectly due to lack of their available arthropod prey, whereas aminocarb and Bt did not have any impacts on small mammals (Innes and Bendell 1988). Relationships among mammal species may also be indirectly affected as a consequence of food depletion. Thus, while diazinon and carbaryl applications on prairie grasslands directly affected cotton rats (Sigmodon hispidus) because they consume contaminated prey insects, other mammals in the community such as prairie voles (Microtus ochrogaster) and house mice (Mus musculus) increased their numbers perhaps due to lack of competition with the rats. When the grassland was sprayed with dimethoate, house mice decreased while prairie voles increased and deer mice (Peromyscus maniculatus) remained at the same density (Barrett and Darnell 1967). 


\section{Impacts on aquatic ecosystems}

Residues of insecticides applied to agriculture find their way to the streams, rivers, ponds, lakes, and ultimately to estuaries and the sea mainly through runoff. Amounts discharged vary among chemicals, but usually not more than $1-6 \%$ of the applied amount goes into the water systems in one season. In addition, spray droplets can fall directly onto the water surfaces of agricultural ditches, streams and ponds near the fields, thus causing unintended damage to their aquatic communities because neurotoxic insecticides are particularly toxic to fish and crustaceans (Table 2). The adoption of buffer strips and vegetated barriers to stop drift contamination of water bodies is a recommended management practice in many developed countries, one that can reduce drift by $95 \%$.

\subsection{Invertebrates}

Insecticides can eliminate entire populations of zooplankton species even at very small concentrations in water and sediments. For instance, residues of imidacloprid at about 1 $\mu \mathrm{g} / \mathrm{L}$ in experimental rice paddies wiped out several ostracod and cladoceran species, as well as one species of Chironomus larvae (Sánchez-Bayo and Goka 2006). Chlorpyrifos decimates zooplankton communities at concentrations above $0.1 \mu \mathrm{g} / \mathrm{L}$ (López-Mancisidor et al. 2008), introducing indirect effects due to shifts in competition and predation between populations. Thus, a sudden collapse in cladoceran populations usually results in rotifers increasing as a consequence of reduced competition for food, but only when other predatory pressures on the rotifers are also suppressed by the insecticides. This is because rotifers are usually more tolerant of OP and carbamate insecticides than the cladocerans. Alternatively, when the copepods in the community are eliminated by $10 \mu \mathrm{g} / \mathrm{L}$ of neem (azadirachtin a.i.) the cladocerans increase concomitantly (Kreutzweiser et al. 2004). The most common indirect effect of the insecticide-impacted zooplankton communities is the surge in algae blooms due to reduced grazing pressure by micro-crustaceans in the ecosystem. When primary producers such as algae grow out of control due to the elimination of herbivorous zooplankton, the $\mathrm{pH}$ and oxygen concentration of the waters increase. However, this effect, does not last long because the organisms killed by the insecticide are then decomposed by fungi and bacteria, thus counteracting to some extent those chemical changes in the water (Schäfer et al. 2011). These community and ecological effects have been observed with many insecticides, and trials on Sahelian ponds have shown that pyrethroids, carbamate and OP insecticides have greater impacts on the zooplankton communities (Anostraca and Branchiopoda) and aquatic insects (Notonectidae) than diflubenzuron and fipronil (Lahr 1998).

Apart from zooplankton, other invertebrates such as aquatic insects, their larvae (nauplii), and worms are affected by insecticide drift or in runoff. Caddisflies, mayflies and stoneflies nauplii, amphipods, isopods and shrimps are decomposers of plant litter and dead organisms, whereas dragonflies, Dytiscidae and Hydrophilidae beetles, backswimmers, striders, etc. are predators: all of them are very sensitive to neurotoxic insecticides and IGR (Table 2). Several species of invertebrate communities such as these were eliminated when surface runoff after rainfall resulted in contamination with parathion-ethyl, lindane and fenvalerate in an agricultural catchment in Germany (Liess and Schulz 1999). Often, mobile species like the amphipod Gammarus sp. move to less contaminated sections to avoid direct insecticidal effects. Elimination of decomposers from the aquatic communities due to insecticides resulted in a three- to five-fold decrease in leaf-litter decomposition in 16 French 
streams (Schäfer et al. 2007). Such impacts can affect several kilometres of river downstream, because many aquatic organisms, including fish, rely on particulate organic matter input from upstream sections. Shrimps, in particular, are very sensitive to pyrethroids and fipronil. For instance, populations of grass shrimp (Palaemonetes pugio) were eliminated from estuarine mesocosms treated at $5 \mathrm{mg} / \mathrm{L}$ fipronil, and reduced $60 \%$ at 0.35 $\mathrm{mg} / \mathrm{L}$, whereas oysters, clams or fish (Cyprinidon variegatus) in the same mesocosms were not affected at all (Wirth et al. 2004). Among the decomposers and shredders of the benthic communities, midge larvae and amphipods are very sensitive to OP insecticides and were severely affected in wetlands treated with phorate $(1.2-4.8 \mathrm{~kg} / \mathrm{ha})$, whereas leeches, snails, worms and ostracods were hardly affected (Dieter et al. 1996). For this reason, midges and amphipods are preferred sentinel species for the detection of pesticide contamination in rivers, estuaries and coastal waters. Recovery of the impacted communities can take from 12 months in the case of zooplankton (van den Brink et al. 1996) and aquatic larvae (Dieter et al. 1996), to several months in the case of macroinvertebrates, and for some species recovery may not happen if runoff insecticide inputs keep occurring over the years (Liess and Schulz 1999). Apart from the sensitivity of certain taxa to particular pesticides, recovery of the community depends to some extent on the climatic conditions and the agricultural practices. Thus, in tropical agriculture, where high quantities of insecticides are applied, the toxic levels in ditches and rivers may be offset by the faster dissipation that such compounds undergo in the warm and humid conditions of the tropics. After some 20 years of treatments with a diverse array of larvicides (temephos, pyraclofos, carbosulfan, permethrin, Bt, etc.) for the control of the blackfly (Simulium damnosum) -the main vector of blindness disease-, the aquatic communities of African rivers revealed only temporary changes in structure that did not compromise the overall functionality of the aquatic ecosystems (Crosa et al. 1998).

\subsection{Vertebrates}

Fish are very susceptible to pyrethroid insecticides (Table 2). When esfenvalerate drift or runoff residues reached ponds containing bluegill (Lepomis macrochirus), the small fry $(<2$ $\mathrm{cm})$ went missing in ponds with the highest concentrations $(2 \mu \mathrm{g} / \mathrm{L})$ (Webber et al. 1992). Most pyrethroid impacts, however, are transient and fish recover quickly after the residues dissipate. Impacts on fish communities by insecticides are more likely the result of indirect effects through the food chain, but studies at the community level are rare. Some understanding has come from insecticide spills into rivers. Thus, a spill of toxaphene from a cattle dip tank in August 1978 affected most fish species in a $26 \mathrm{~km}$ stretch of the Hluhluwe River (Natal, South Africa). Although most fish reappeared after a year, due to migration from upstream tributaries, their populations were very low. The bioaccumulation of this OC insecticide was apparent in fish-eating birds such as herons and raptors, some of which were endangered (Brooks and Gardner 1981). However, repeated application of insecticides in African rivers for the control of onchocerciasis (see above) does not show any clear trend in the fish populations, although some species have been reduced temporarily.

The fact that many amphibian population declines occur in intensive agricultural areas has alerted some researchers. Some blame the combination of indirect effects from insecticides and herbicides, which introduce a cascade of events affecting negatively the feeding and growth of tadpoles plus sublethal effects involving stress and parasite infections. Endocrine disruption affecting larval growth and development of tadpoles has also been observed with mixtures of insecticides and herbicides in mesocosms (Hayes et al. 2006). These impacts together with other intensive farming practices, such as the use of fertilizers, may be in part 
responsible for declines in some amphibian species (reviewed in Mann et al. 2009). Nevertheless, tadpoles of southern leopard frogs (Rana sphenocephala) increased in numbers when carbaryl reduced their predators in a mesocosms; the unforseen effect of such a boost was increased intra-specific competition for the periphyton, which resulted in smaller metamorphs. Similar impacts were observed with malathion on six amphibian species in more complex aquatic communities (Relyea and Hoverman 2008). However, pesticidetreated rice paddies continue to be a valuable haven for many species of frogs, since herons are not attracted to conventional fields because they have less foraging value than organic ones.

Studies on insecticide impacts in communities of aquatic reptiles, birds and mammals are non-existent. All we know is that residues of persistent OC insecticides are found in large marine mammals throughout the world, particularly whales, dolphins and seals in the Mediterranean regions and the west coast of North America (Aguilar et al. 2002). Recent studies on loggerhead sea turtles (Caretta caretta) confirm the widespread contamination of the oceans with DDT, toxaphene, mirex, chlordanes, lindane, dieldrin and other persistent organic pollutants (Alava et al. 2011), but the impacts these residues may have on the ecology of these animals is only hypothetical.

\section{Risk assessment}

Whilst the term "hazard" indicates the existence of potential harm, "risk" refers to the probability of harm occurring. Risk assessments aim at preventing or at least minimising such impacts based on our current knowledge of the hazardous pesticides used in agriculture, forestry and urban environments. Here I described some of the actual risks posed by commonly used insecticides, either in real field situations or on artificial, simulated ecosystems. And yet, despite this evidence, current methods to assess the risk of pesticides are still inadequate because the overwhelming majority of the models use simple LD50 or LC50 estimates. As we have seen, this type of information is limited, since the sublethal effects of insecticides can affect populations at concentrations far lower than those determined in acute toxicity tests. For example, Giddings et al. (2001) showed that the LOEC values for the pyrethroids cypermethrin and esfenvalerate in mesocosms were one tenth of those derived in laboratory experiments. In addition, indirect effects on other species of the community are almost unpredictable since we do not have models to describe them.

A distinction must be made, however, between the two types of risk assessment currently in use. Firstly, ecological risk assessment methods that aim at protecting the ecosystem, its communities and species have improved remarkably in the last decade. Species sensitivity distributions (SSD) take into account either the lethal or the no-observed effect levels of all species tested so far, allowing estimation of the median hazard levels for a given percentile of species (e.g. HC5 for effect on $5 \%$ of species, equivalent to $95 \%$ species protection) (Posthuma et al. 2002). Although the accuracy of these predictions relies entirely on the number of species tested and the taxa covered in the distribution, the SSD model has been validated for both aquatic and terrestrial communities. Models based on SSD are currently used to set water quality and sediment guidelines in many countries.

The second type of risk assessment is for regulatory purposes in agriculture or forestry. Here the aim is to minimise the impact on ecosystems to levels accepted by the community, which is not necessarily the same as protecting the integrity of the ecosystems. As a 
consequence, the registration process considers several 'tiers' of assessment. Testing for lethal dose or concentration in a few species representative of a community of organisms (e.g. Daphnia, trout or another fish, honeybee, rat and quail or duck) is usually the norm for the first tier of the assessment. Higher tiers may involve mesocosm or field studies, but only when the data for the first tier appears to be insufficient to prove the 'safety' of the chemical. Safety, of course, may apply to some organisms but not others, as discussed above (see Table 2). Although recommendations and regulations for insecticide assessment, registration and re-evaluation are now in place in most of the developed world (reviewed by GreigSmith 1992), there are many discrepancies between the regulations of various countries even for the same chemical (Devine and Furlong 2007). Apart from persistent OC insecticides, most of which are banned in developed countries, any other insecticide is allowed in practice as long as certain precautions and management options are put in place. Pesticide labels are supposed to take care of this, but this assumes that all farmers have a good level of literacy, which is far from the reality. The problem lies in the implementation of those precautionary measures among the farming communities, more so in countries with little or no legislative power in this matter. Not surprisingly, developing countries are lagging behind in these matters.

Since the bulk of insecticides is being used in developing countries, most of which are located in the tropical or subtropical regions of the world, insecticide risk assessment should be a priority in such regions. Using tropical taxa for the regulatory testing has been suggested, arguing that their species may differ in susceptibility to pesticides. However, most tropical species do not differ in sensitivity from their temperate counterparts (Daam et al. 2009; Kwok et al. 2007). As for the higher dissipation rates of pesticides in the tropical regions, which may minimise exposure to organisms, most chemicals appear to pose a similar risk as in temperate regions because the increasing losses by degradation or volatilisation are usually counterbalanced by greater desorption and movement of residues into the aquatic environment (Sanchez-Bayo and Hyne 2011).

\section{Insecticides in sustainable agriculture}

There is no doubt that insecticides help produce higher crop yields because they reduce substantially the damage inflicted by insects and other pests (Pimentel 2005). However, the ecological cost of conventional agricultural practices is also evident, even if the extent of the disturbances they cause varies markedly among compounds. Except for a few accidental cases, most of the impacts described in this chapter occur when insecticides are used as recommended. Impacts range from short-term imbalances in the planktonic and invertebrate communities to long-term reduction in the reproductive ability of some bird and fish species, which may lead to the extinction of the populations affected. The severity of the impacts depends not only on the toxicity of the compounds but also on unforeseen sublethal and indirect effects they may cause. Physico-chemical characteristics of the compounds are equally important, since they determine their persistence and bioaccumulation properties in organisms, thus being intimately associated with the exposure and long-term effects in the ecosystems. It has also been shown that such ecological damage is widespread throughout the world, although it is more prevalent in agricultural areas of temperate and tropical regions. On a positive note, the capacity of the ecosystems to recover from insecticide pulses is remarkable. Even the worst cases of 
pesticide contamination, such as the storehouse spill in the Rhine in November 1986, can return to normality after one or two years (Capel et al. 1988).

Awareness of the impacts that insecticides are having in our world may help introduce management practices with the aim of reducing and mitigating those impacts. Historically, such awareness has prompted the search for new pest control technologies such as biological control, pheromone traps, attractants and others included under the current IPM practices. It has also helped develop on-site mitigating technologies such as phytoremediation. Certainly, IPM has not achieved a reduction in overall pesticide usage, as it was originally intended, even in areas where that concept is very popular (e.g., the UK and California), but at least has kept insecticide use static during a period of increasing agricultural intensification (Devine and Furlong 2007). Moreover, IPM practices are only compatible with selective and non-persistent insecticides that do not affect predatory and parasitic organisms. Thus, it excludes most of the highly toxic, broad-spectrum and persistent insecticides, which are the ones that cause most damage to the environment. In addition, IPM practices are economically more affordable because of the low insecticide inputs they require, and yield profit margins about $2 \%$ higher than conventional agriculture (Young et al. 2001). Hence, the adoption of IPM in poor countries is imperative, not only to avoid the pollution and ecological degradation of their environment but most importantly to help poor farmers develop a sustainable agriculture which does not depend on costly chemical inputs.

Finally, ecological damage usually cannot be measured in economic terms, unless they involved losses of game, livestock, soil fertility or any other issue with economic value. This only brings in confusion among the public, farmers, stakeholders and politicians, who see the reality from different points of view and, therefore, hold very different opinions on these matters. Thus, the decisions following specific risk assessments of insecticides are always subjective, since there is no metric that can compare the ecological consequences of using a given insecticide to the economic profits it may bring to a particular farming community or a country.

\section{Conclusion}

The environmental pollution and a subtle undermining of the ecosystems brought about by the constant use of pesticides should not be dismissed as trivial. Ultimately, we all depend on the services that the environment provides for our own health and food production. Even if natural ecosystems are resilient and populations of organisms can recover relatively quickly, the constant use of insecticides in agricultural lands and forests year after year is reducing the food supplies for many vertebrate species, i.e. birds and possibly frogs, lizards and small insectivorous mammals. Thus, the increase in agricultural productivity we enjoy is paid for by a reduction of aquatic and terrestrial communities of organisms at a global scale.

\section{References}

Aguilar, A., Borrell, A. \& Reijnders, P.J.H. (2002). Geographical and temporal variation in levels of organochlorine contaminants in marine mammals. Mar. Environ. Res. 53(5):425-452. 
Alava, J.J., Keller, J.M., Wyneken, J., Crowder, L., Scott, G. \& Kucklick, J.R. (2011). Geographical variation of persistent organic pollutants in eggs of threatened loggerhead sea turtles (Caretta caretta) from southeastern United States. Environ. Toxicol. Chem. 30(7):1677-1688.

Badji, C.A., Guedes, R.N.C., Silva, A.A., Correa, A.S., Queiroz, M.E.L.R. \& Michereff Filho, M. (2007). Non-target impact of deltamethrin on soil arthropods of maize fields under conventional and no-tillage cultivation. J. Appl. Entomol. 131(1):50-58.

Barrett, G.W. (1988). Effects of Sevin on small mammal populations in agricultural and oil field ecosystems. J. Mammal. 69:731-739.

Barrett, G.W. \& Darnell, R.M. (1967). Effects of dimethoate on small mammal populations. Am. Midland Nat. 77:164-175.

Bishop, C.A., Boermans, H.J., Ng, P., Campbell, G.D. \& Struger, J. (1998). Health of tree swallows (Tachycineta bicolor) nesting in pesticide-sprayed apple orchards in Ontario, Canada. II. Sex and thyroid hormone concentrations in testes development. J. Toxicol. Environ. Health A 55(8):561-581.

Bonmatin, J.M., Marchand, P.A., Charvet, R., Moineau, I., Bengsch, E.R. \& Colin, M.E. (2005). Quantification of imidacloprid uptake in maize crops. J. Agric. Food Chem. 53(13):5336-5341.

Brooks, P. \& Gardner, B. (1981). Effect of cattle dip containing toxaphene on the fauna of a South African river. J. Limnol. Soc. South Afr. 6(2):113-118.

Broomhall, S.D. (2002). The effects of endosulfan and variable water temperature on survivorship and subsequent vulnerability to predation in Litoria citropa tadpoles Aquat. Toxicol. 61:243-250.

Brown, A.W.A. (1978). Ecology of Pesticides. John Wiley \& Sons, Inc., 0-471-10790-5, New York.

Butler, C.D., Beckage, N.E. \& Trumble, J.T. (2009). Effects of terrestrial pollutants on insect parasitoids. Environ. Toxicol. Chem. 28(6):1111-1119.

Capel, P.D., Giger, W., Reichert, P. \& Wanner, O. (1988). Accidental input of pesticides into the Rhine River. Environ. Sci. Technol. 22(9):992-997.

Capowiez, Y., Bastardie, F. \& Costagliola, G. (2006). Sublethal effects of imidacloprid on the burrowing behaviour of two earthworm species: modifications of the 3D burrow systems in artificial cores and consequences on gas diffusion in soil. Soil Biol. Biochem. 38(2):285-293.

Carriquiriborde, P., Diaz, J., Mugni, H., Bonetto, C. \& Ronco, A.E. (2007). Impact of cypermethrin on stream fish populations under field-use in biotech-soybean production. Chemosphere 68(4):613-621.

Chandler, G.T., Cary, T.L., Volz, D.C., Walse, S.S., Ferry, J.L. \& Klosterha, S.L. (2004). Fipronil effects on estuarine copepod (Amphiascus tenuiremis) development, fertility, and reproduction: a rapid life-cycle assay in 96-well microplate format. Environ. Toxicol. Chem. 23(1):117-124.

Chen, M., Liu, Z.-C., Ye, G.-y., Shen, Z.-c., Hu, C., Peng, Y.-f., Altosaar, I. \& Shelton, A.M. (2007). Impacts of transgenic cry1 Ab rice on non-target planthoppers and their main predator Cyrtorhinus lividipennis (Hemiptera : Miridae) - A case study of the compatibility of Bt rice with biological control. Biol. Control 42(2):242-250. 
Clark, D.R. (2001). DDT and the decline of free-tailed bats (Tadarida brasiliensis) at Carlsbad Cavern, New Mexico Arch. Environ. Contam. Toxicol. 40(4):537-543.

Cold, A. \& Forbes, V.E. (2004). Consequences of a short pulse of pesticide exposure for survival and reproduction of Gammarus pulex. Aquat. Toxicol. 67(3):287-299.

Cooke, A.S. (1973). Shell thinning in avian eggs by environmental pollutants. Environ. Pollut. 4:85-152.

Cox, R.L. \& Wilson, W.T. (1984). Effects of permethrin on the behavior of individually tagged honey bees, Apis mellifera L. (Hymenoptera: Apidae). Environ. Entomol. 13(2):375-378.

Crosa, G., Yameogo, L., Calamari, D. \& Hougard, J.M. (1998). Long term quantitative ecological assessment of insecticides treatments in four African Rivers: a methodological approach. Chemosphere 37:2847-2858.

Custer, T.W., Custer, C.M., Hines, R.K., Gutreuter, S., Stromborg, K.L., Allen, P.D. \& Melancon, M.J. (1999). Organochlorine contaminants and reproductive success of double-crested cormorants from Green Bay, Wisconsin, USA. Environ. Toxicol. Chem. 18(6):1209-1217.

Custer, T.W., Hensler, G.L. \& Kaiser, T.E. (1983). Clutch size, reproductive success, and organochlorine contaminants in Atlantic coast black-crowned night-herons. Auk 100:699-710.

Daam, M.A., Satapornvanit, K., van den Brink, P.J. \& Nogueira, A.J.A. (2009). Sensitivity of macroinvertebrates to carbendazim under semi-field conditions in Thailand: implications for the use of temperate toxicity data in a tropical risk assessment of fungicides. Chemosphere 74(9):1187-1194.

Daryanto, I. (1998). Pesticide management policy in Indonesia. In: Seeking Agricultural Produce Free of Pesticide Residues, Kennedy, I.R. et al., editors, pp. 31-36, Australian Centre for International Agricultural Research (ACIAR), Canberra

Devine, G.J. \& Furlong, M.J. (2007). Insecticide use: contexts and ecological consequences. Agric. Human Values 24:281-306.

Dieter, C.D., Duffy, W.G. \& Flake, L.D. (1996). The effect of phorate on wetland macroinvertebrates. Environ. Toxicol. Chem. 15(3):308-312.

Dittbrenner, N., Triebskorn, R., Moser, I. \& Capowiez, Y. (2010). Physiological and behavioural effects of imidacloprid on two ecologically relevant earthworm species (Lumbricus terrestris and Aporrectodea caliginosa). Ecotoxicology 19:1567-1573.

Donald, P.F., Green, R.E. \& Heath, M.F. (2001). Agricultural intensification and the collapse of Europe's farmland bird populations. Proc. $R$ Soc. B. 268(1462):25-29.

Douthwaite, R.J. (1992). Effects of DDT treatments applied for tsetse fly control on whiteheaded black chat (Thamnolaea arnoti) populations in Zimbabwe. Part I: Population changes. Ecotoxicology 1(1):17-30.

Dutta, H.M. \& Meijer, H.J.M. (2003). Sublethal effects of diazinon on the structure of the testis of bluegill, Lepomis macrochirus: a microscopic analysis. Environ. Pollut. 125(3):355-360.

Edwards, C.A. \& Thompson, A.R. (1973). Pesticides and the soil fauna. Residue Rev. 45:1-79. 
Elliott, J.E., Birmingham, A.L., Wilson, L.K., McAdie, M., Trudeau, S. \& Mineau, P. (2008). Fonofos poisons raptors and waterfowl several months after granular application. Environ. Toxicol. Chem. 27(2):452-460.

Epstein, D.L., Zack, R.S., Brunner, J.F., Gut, L. \& Brown, J.J. (2000). Effects of broad-spectrum insecticides on epigeal arthropod biodiversity in Pacific Northwest apple orchards Environ. Entomol. 29(2):340-348.

FAO (2004). The State of Food Insecurity in the World. Rome: Food and Agricultural Organisation of the United Nations. $40 \mathrm{p}$.

FAO (2010). FAOSTAT On-line Statistical Service. Food and Agriculture Organization of the United Nations.

Foissner, W. (1997). Protozoa as bioindicators in agroecosystems, with emphasis on farming practices, biocides, and biodiversity Agric. Ecosyst. Environ. 62(2-3):93-103.

Fountain, M.T., Brown, V.K., Gange, A.C., Symondson, W.O.C. \& Murray, P.J. (2007). The effects of the insecticide chlorpyrifos on spider and Collembola communities. Pedobiologia 51(2):147-158.

George, J.L. \& Stickel, W.H. (1949). Wildlife effects of DDT dust used for tick control on a Texas prairie. Am. Midland Nat. 42(1):228-237.

Giddings, J.M., Solomon, K.R. \& Maund, S.J. (2001). Probabilistic risk assessment of cotton pyrethroids: II. Aquatic mesocosms and field studies. Environ. Toxicol. Chem. 20(3):660-668.

Goldstein, M., Lacher, T.J., Zaccagnini, M., Parker, M. \& Hooper, M. (1999). Monitoring and assessment of Swainson's hawks in Argentina following restrictions on monocrotophos use, 1996-97. Ecotoxicology 8(3):215-224.

Greig-Smith, P.W. (1992). A european perspective on ecological risk assessment, illustrated by pesticide registration procedures in the United Kingdom. Environ. Toxicol. Chem. 11(12):1673-1689.

Greig-Smith, P.W., Thompson, H.M., Hardy, A.R., Bew, M.H., Findlay, E. \& Stevenson, J.H. (1994). Incidents of poisoning of honeybees (Apis mellifera) by agricultural pesticides in Great Britain 1981-1991. Crop Protection 13:567-581.

Grue, C.E., Powell, G.V.N. \& McChesney, M.J. (1982). Care of nestlings by wild female starlings exposed to an organophosphate pesticide. J. Appl. Ecol. 19:327-335.

Guillette, L.J., Gross, T.S., Gross, D.A., Rooney, A.A. \& Percival, H.F. (1995). Gonadal steroidogenesis in vitro from juvenile alligators obtained from contaminated or control lakes. Environ. Health Perspect. 103(Suppl. 4):31-36.

Hardy, A.R., Westlake, G.E., Lloyd, G.A., Brown, P.M., Greig-Smith, P.W., Fletcher, M.R., Tarrant, K.A. \& Stanley, P.I. (1993). An intensive field trial to assess hazards to birds and mammals from the use of methiocarb as a bird repellent on ripening cherries. Ecotoxicology 2(1):1-31.

Hayes, T.B., Case, P., Chui, S., Chung, D., Haeffele, C., Haston, K., Lee, M., Mai, V.P., Marjuoa, Y., Parker, J.et al. (2006). Pesticide mixtures, endocrine disruption and amphibian declines: are we underestimating the impact? Environ. Health Perspect. 114(Suppl. 1):40-50.

Hernández, M., González, L.M., Oria, J., Sánchez, R. \& Arroyo, B. (2008). Influence of contamination by organochlorine pesticides and polychlorinated biphenyls on the 
breeding of the Spanish imperial eagle (Aquila adalberti). Environ. Toxicol. Chem. 27(2):433-441.

Innes, D.G.L. \& Bendell, J.F. (1988). The effects on small-mammal populations of aerial applications of Bacillus thuringiensis, fenitrothion, and Matacil ${ }^{\circledR}$ used against jack pine budworm in Ontario Can. J. Zool. 67(5):1318-323.

Iwasa, M., Nakamura, T., Fukaki, K. \& Yamashita, N. (2005). Nontarget effects of ivermectin on coprophagous insects in Japan. Environ. Entomol. 34(6):1485-1492.

James, D.G. \& Whitney, J. (1993). Mite populations on grapevines in south-eastern Australia: implications for biological control of grapevine mites (Acarina: Tenuipalpidae, Eriophyidae) Exp. Appl. Acarol. 17(4):259-270.

Jergentz, S., Pessacq, P., Mugni, H., Bonetto, C. \& Schulz, R. (2004). Linking in situ bioassays and population dynamics of macroinvertebrates to assess agricultural contamination in streams of the Argentine pampa. Ecotoxicol. Environ. Saf. 59(1):133-141.

Kashiwada, S., Tatsuta, H., Kameshiro, M., Sugaya, Y., Sabo-Attwood, T., Chandler, G.T., Ferguson, P.L. \& Goka, K. (2008). Stage-dependent differences in effects of carbaryl on population growth rate in Japanese medaka (Oryzias latipes). Environ. Toxicol. Chem. 27(11):2397-2402.

Koehler, H.H. (1992). The use of soil mesofauna for the judgement of chemical impact on ecosystems. Agric. Ecosyst. Environ. 40(1-4):193-205.

Kreutzweiser, D.P., Back, R.C., Sutton, T.M., Pangle, K.L. \& Thompson, D.G. (2004). Aquatic mesocosm assessments of a neem (azadirachtin) insecticide at environmentally realistic concentrations - 2: zooplankton community responses and recovery. Ecotoxicol. Environ. Saf. 59(2):194-204.

Kreutzweiser, D.P., Good, K.P., Chartrand, D.T., Scarr, T.A., Holmes, S.B. \& Thompson, D.G. (2008). Effects on litter-dwelling earthworms and microbial decomposition of soilapplied imidacloprid for control of wood-boring insects. Pest Manag. Sci. 64(2):112118.

Krüger, K. \& Scholtz, C.H. (1997). Lethal and sublethal effects of ivermectin on the dungbreeding bettles Euoniticellus intermedius (Reiche) and Onitis alexis Klug (Coleoptera, Scarabaeidae) Agric. Ecosyst. Environ. 61:123-131.

Kumar, A. \& Chapman, J.C. (2001). Profenofos residues in wild fish from cotton-growing areas of New South Wales. J. Environ. Qual. 30:740-750.

Kwok, K.W., Leung, K.M., Lui, G.S., Chu, V.K., Lam, P.K., Morritt, D., Maltby, L., Brock, T.C., van den Brink, P.J., Warne, M.S.J.et al. (2007). Comparison of tropical and temperate freshwater animal species' acute sensitivities to chemicals: implications for deriving safe extrapolation factors. Integr. Environ. Assess. Manage. 3:49-67.

Lahr, J. (1998). An ecological assessment of the hazard of eight insecticides used in desert locust control, to invertebrates in temporary ponds in the Sahel. Aquat. Ecol. 32(2):153-162.

Li, S.Y., Harmsen, R. \& Thistlewood, H.M.A. (1992). The effect of pyrethroid lambdacyhalothrin applications on the spatial distribution of phytophagous and predatory mites in apple orchards Exp. Appl. Acarol. 15(4):259-269. 
Liess, M. \& Schulz, R. (1999). Linking insecticide contamination and population response in an agricultural stream. Environ. Toxicol. Chem. 18(9):1948-1955.

Lockhart, W.L., Metner, D.A., Ward, F.J. \& Swanson, G.M. (1985). Population and cholinesterase responses in fish exposed to malathion sprays. Pestic. Biochem. Physiol. 24(1):12-18.

López-Mancisidor, P., Carbonell, G., Fernández, C. \& Tarazona, J.V. (2008). Ecological impact of repeated applications of chlorpyrifos on zooplankton community in mesocosms under Mediterranean conditions. Ecotoxicology 17(8):811-825.

Luo, Y., Zang, Y., Zhong, Y. \& Kong, Z. (1999). Toxicological study of two novel pesticides on earthworm Eisenia foetida. Chemosphere 39(13):2347-2356.

Mann, R.M., Hyne, R.V., Choung, C.B. \& Wilson, S.P. (2009). Amphibians and agricultural chemicals: review of the risks in a complex environment. Environ. Pollut. 157(11):2903-2927.

Manning, T. (2005). Endocrine disrupting chemicals - A review of the state of the science. Australas. J. Ecotoxicol. 11(1):1-52.

Maxim, L. \& Sluijs, J.P.v.d. (2007). Uncertainty: Cause or effect of stakeholders' debates? Analysis of a case study: the risk for honeybees of the insecticide Gaucho. Sci. Total Environ. 376:1-17.

McLean, R., Spillane, J. \& Miles, J. (1975). A prospective study of the effects of ultralow volume (ULV) aerial application of malathion on epidemic Plasmodium falciparum malaria. 3. Ecological aspects. Am. J. Trop. Med. Hyg. 24(2):193-198.

Mendelssohn, H. \& Paz, U. (1977). Mass mortality of birds of prey caused by Azodrin, an organophosphorus insecticide. Biol. Conserv. 11(3):163-170.

Mineau, P. (2003). Avian Species. In: Encyclopedia of Agrochemicals, Plimmer, J.R. et al., editors, pp. 1-27, John Wiley \& Sons, Inc.,

Mineau, P., Fletcher, M.R., Glaser, L.C., Thomas, N.J., Brassard, C., Wilson, L.K., Elliott, J.E., Lyon, L.A., Henny, C.J., Bollinger, T.et al. (1999). Poisoning of raptors with organophosphorous and carbamate pesticides with emphasis on Canada, the United States and the United Kigdom. J. Raptor Res. 33(1):1-37.

Morris, R.D. (1970). The effects of endrin on Microtus and Peromyscus. I. Unenclosed field populations Can. J. Zool. 48(4):685-708.

Newton, I. (2004). The recent declines of farmland bird populations in Britain: an appraisal of causal factors and conservation actions. Ibis 146:579-600.

Niño, E.L., Sorenson, C.E., Washburn, S.P. \& Watson, D.W. (2009). Effects of the insect growth regulator, methoprene, on Onthophagus taurus (Coleoptera: Scarabaeidae). Environ. Entomol. 38(2):493-498.

Pain, D.J., Gargi, R., Cunningham, A.A., Jones, A. \& Prakash, V. (2004). Mortality of globally threatened Sarus cranes (Grus antigon) from monocrotophos poisoning in India. Sci. Total Environ. 326(1-3):55-61.

Peakall, D.B. \& Carter, N. 1997 Decreases in farmland birds and agricultural practices: a huge ecotoxicological experiment. Toxicol. Ecotoxicol. News:162-163.

Perfecto, I. (1990). Indirect and direct effects in a tropical agroecosystem: the maize-pest-ant system in Nicaragua. Ecology 71(6):2125-2134. 
Peveling, R., Rafanomezantsoa, J.-J., Razafinirina, R., Tovonkery, R. \& Zafimaniry, G. (1999). Environmental impact of the locust control agents fenitrothion, fenitrothionesfenvalerate and triflumuron on terrestrial arthropods in Madagascar. Crop Protection 18:659-676.

Pickett, A.D. (1962). Pesticides and the biological control of arthropod pests. World Rev. Pest Control 1:19-25.

Pimentel, D. (2005). Environmental and economic costs of the application of pesticides primarily in the United States. Environ. Develop. Sustain. 7(2):229-252.

Posthuma, L., II, G.W.S. \& Traas, T.P., editors., (2002). Species Sensitivity Distributions in Ecotoxicology, CRC Press LLC, 1-56670-578-9, Boca Raton, FL.

Potts, G.R. (1986). The Partridge - Pesticides, Predation and Conservation. Collins, London, UK.

Powell, G.V.N. (1984). Reproduction by an altricial songbird, the red winged blackbird, in fields treated with the organophosphate insecticide fenthion. J. Appl. Ecol. 21:83-95.

Reinecke, S. \& Reinecke, A. (2007). The impact of organophosphate pesticides in orchards on earthworms in the Western Cape, South Africa. Ecotoxicol. Environ. Saf. 66(2):244251.

Relyea, Rick A. (2004). Synergistic impacts of malathion and predatory stress on six species of North American tadpoles. Environ. Toxicol. Chem. 23(4):1080-1084.

Relyea, R.A. \& Hoverman, J.T. (2008). Interactive effects of predators and a pesticide on aquatic communities. Oikos 117(11):1647-1658.

Rohr, J.R., Raffel, T.R., Sessions, S.K. \& Hudson, P.J. (2008). Understanding the net effects of pesticides on amphibian trematode infections. Ecol. Appl. 18(7):1743-1753.

Rose, R. \& Dively, G.P. (2007). Effects of insecticide-treated and lepidopteran-active Bt transgenic sweet corn on the abundance and diversity of arthropods Environ. Entomol. 36(5):1254-1268.

Sánchez-Bayo, F. \& Goka, K. (2006). Ecological effects of the insecticide imidacloprid and a pollutant from antidandruff shampoo in experimental rice fields. Environ. Toxicol. Chem. 25(6):1677-1687.

Sánchez-Bayo, F. \& Hyne, R.V. (2011). Comparison of environmental risks of pesticides between tropical and nontropical regions. Integr. Environ. Assess. Manage. 7(4):577586

Sánchez-Bayo, F., Yamashita, H., Osaka, R., Yoneda, M. \& Goka, K. (2007). Ecological effects of imidacloprid on arthropod communities in and around a vegetable crop. $J$. Environ. Sci. Health B 42(3):279-286.

Schäfer, R.B., Brink, P.J.v.d. \& Liess, M. (2011). Impacts of pesticides on freshwater ecosystems. In: Ecological Impact of Toxic Chemicals, Sánchez-Bayo, F. et al., editors, pp. 111-137, Bentham Science Publishers, 978-1-60805-121-2, Online

Schäfer, R.B., Caquet, T., Siimes, K., Mueller, R., Lagadic, L. \& Liess, M. (2007). Effects of pesticides on community structure and ecosystem functions in agricultural streams of three biogeographical regions in Europe. Sci. Total Environ. 382(2-3):272-285.

Schauber, E.M., Edge, W.D. \& Wolff, J.O. (1997). Insecticide effects on small mammals: influence of vegetation structure and diet. Ecol. Appl. 7(1):143-157.

Schulz, R. \& Liess, M. (1999). A field study of the effects of agriculturally derived insecticide input on stream macroinvertebrate dynamics. Aquat. Toxicol. 46:155-176. 
Sharma, D.C. \& Kashyap, N.P. (2002). Impact of pesticidal spray on seasonal availability of natural predators and parasitoids in the tea ecosystem. J. Biol. Control 16(1):31-35.

Sheffield, S.R. \& Lochmiller, R.L. (2001). Effects of field exposure to diazinon on small mammals inhabiting a semienclosed prairie grassland ecosystem. I. Ecological and reproductive effects. Environ. Toxicol. Chem. 20(2):284-296.

Sibly, R.M., Newton, I. \& Walker, C.H. (2000). Effects of dieldrin on population growth rates of sparrowhawks 1963-1986. J. Appl. Ecol. 37(3):540-546.

Stark, J. \& Vargas, R. (2005). Toxicity and hazard assessment of fipronil to Daphnia pulex Ecotoxicol. Environ. Saf. 62(1):11-16.

Stark, J.D. (2001). Population-level effects of the neem insecticide, Neemix on Daphnia pulex. J. Environ. Sci. Health B 36(2):457-465.

Story, P. \& Cox, M. (2001). Review of the effects of organophosphorus and carbamate insecticides on vertebrates. Are there implications for locust management in Australia? Wildl. Res. 28(2):179-193.

Thompson, D.G. (2011). Ecological impacts of major forest-use pesticides. In: Ecological Impact of Toxic Chemicals, Sánchez-Bayo, F. et al., editors, pp. 88-110, Bentham Science Publishers, 978-1-60805-121-2, Online

Thompson, H.M. (2001). Assessing the exposure and toxicity of pesticides to bumblebees (Bombus sp.). Apidologie 32:305-321.

van den Brink, P.J., Wijngaarden, R.P.A.V., Lucassen, W.G.H., Brock, T.C.M. \& Leeuwangh, P. (1996). Effects of the insecticide Dursban 4E (active ingredient chlorpyrifos) in outdoor experimental ditches: II. Invertebrate community responses and recovery. Environ. Toxicol. Chem. 15(7):1143-1153.

Wadhwa, S. \& Gill, R.S. (2007). Effect of Bt-cotton on biodiversity of natural enemies J. Biol. Control 21(1):9-15.

Walker, M.K., Stufkens, M.A.W. \& Wallace, A.R. (2007). Indirect non-target effects of insecticides on Tasmanian brown lacewing (Micromus tasmaniae) from feeding on lettuce aphid (Nasonovia ribisnigri). Biol. Control 43(1):31-40.

Wang, G., Edge, W.D. \& Wolff, J.O. (2001). Rainfall and Guthion $2 S$ interactions affect graytailed vole demography. Ecol. Appl. 11(3):928-933.

Webber, E.C., Deutsch, W.G., Bayne, D.R. \& Seesock, W.C. (1992). Ecosystem-level testing of a synthetic pyrethroid insecticide in aquatic mesocosms. Environ. Toxicol. Chem. 11(1):87-105.

Whitford, F. \& Showers, W.B. (1987). Impact of insecticides on composition and abundance of ground-dwelling insect fauna in adult European corn borer (Lepidoptera, Pyralidae) action sites in Iowa, USA. Environ. Entomol. 16(1):231-236.

Wiktelius, S., Chiverton, P.A., Meguenni, H., Bennaceur, M., Ghezal, F., Umeh, E.-D.N., Egwuatu, R.I., Minja, E., Makusi, R., Tukahirwa, E.et al. (1999). Effects of insecticides on non-target organisms in African agroecosystems: a case for establishing regional testing programmes. Agric. Ecosyst. Environ. 75:121131.

Williams, T., Valle, J. \& Viñuela, E. (2003). Is the naturally derived insecticide Spinosad® compatible with insect natural enemies? Biocontrol Sci. Technol. 13(5):459475 . 
Wirth, E.F., Pennington, P.L., Lawton, J.C., DeLorenzo, M.E., Bearden, D., Shaddrix, B., Sivertsen, S. \& Fulton, M.H. (2004). The effects of the contemporary-use insecticide (fipronil) in an estuarine mesocosm. Environ. Pollut. 131(3):365-371.

Young, J.E.B., Griffin, M.J., Alford, D.V. \& Ogilvy, S.E. (2001). Reducing Agrochemical Use on the Arable Farm: The TALISMAN and SCARAB Projects. London, UK: DEFRA. $416 \mathrm{p}$. 


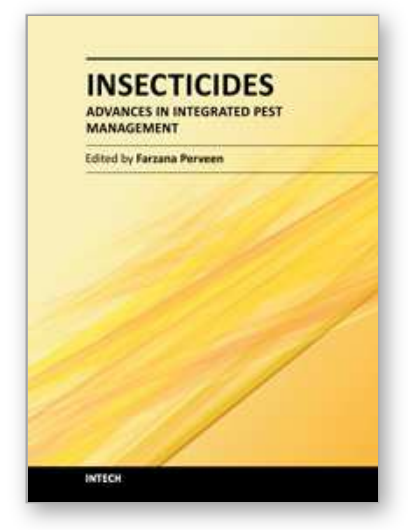

\author{
Insecticides - Advances in Integrated Pest Management \\ Edited by Dr. Farzana Perveen
}

ISBN 978-953-307-780-2

Hard cover, 708 pages

Publisher InTech

Published online 05, January, 2012

Published in print edition January, 2012

This book contains 30 Chapters divided into 5 Sections. Section A covers integrated pest management, alternative insect control strategies, ecological impact of insecticides as well as pesticides and drugs of forensic interest. Section B is dedicated to chemical control and health risks, applications for insecticides, metabolism of pesticides by human cytochrome $\mathrm{p} 450$, etc. Section $\mathrm{C}$ provides biochemical analyses of action of chlorfluazuron, pest control effects on seed yield, chemical ecology, quality control, development of ideal insecticide, insecticide resistance, etc. Section $D$ reviews current analytical methods, electroanalysis of insecticides, insecticide activity and secondary metabolites. Section E provides data contributing to better understanding of biological control through Bacillus sphaericus and B. thuringiensis, entomopathogenic nematodes insecticides, vector-borne disease, etc. The subject matter in this book should attract the reader's concern to support rational decisions regarding the use of pesticides.

\title{
How to reference
}

In order to correctly reference this scholarly work, feel free to copy and paste the following:

Francisco Sánchez-Bayo (2012). Ecological Impacts of Insecticides, Insecticides - Advances in Integrated Pest Management, Dr. Farzana Perveen (Ed.), ISBN: 978-953-307-780-2, InTech, Available from: http://www.intechopen.com/books/insecticides-advances-in-integrated-pest-management/ecological-impactsof-insecticides

\section{INTECH}

open science | open minds

\author{
InTech Europe \\ University Campus STeP Ri \\ Slavka Krautzeka 83/A \\ 51000 Rijeka, Croatia \\ Phone: +385 (51) 770447 \\ Fax: +385 (51) 686166 \\ www.intechopen.com
}

\author{
InTech China \\ Unit 405, Office Block, Hotel Equatorial Shanghai \\ No.65, Yan An Road (West), Shanghai, 200040, China \\ 中国上海市延安西路65号上海国际贵都大饭店办公楼 405 单元 \\ Phone: +86-21-62489820 \\ Fax: $+86-21-62489821$
}


(C) 2012 The Author(s). Licensee IntechOpen. This is an open access article distributed under the terms of the Creative Commons Attribution 3.0 License, which permits unrestricted use, distribution, and reproduction in any medium, provided the original work is properly cited. 